\title{
LEgISLATING LANGUAGE USE IN ALBERTA: A Century of InCIDENTAL Provisions FOR A FUNDAMENTAL MATTER
}

\author{
EDMUND A. AUNGER
}

Language law deals with a matter of fundamental importance, and language rights have been widely recognized as fundamental human rights. Yet ven litlle is known about Alberta's legislative provisions for language use. This article examines those provisions that have had the greatest impact over the past century and places them in their historical context. It also presents a comprehensive overview of the many unheralded provisions and organizes them according to their thematic significance. During Alberta's early decades these language provisions commonly imposed English and repressed minority languages. In more recent years they have promoted a greater tolerance for French and other languages.
Le droit linguistigue a trait d une matière d'importance fondamentale, et les droits lingustiques sont genéralement reconmus comme des droils fondamentaux. Pourtant. en ce qui concerne l'Alberia. les dispositions législatives en matière de langue sont largement ignorées. Cet article étudie les dispositions qui ont eu le plus grand impact depuis un siècle et les situe dans leur contexte historique. /I présente également un survol étendu des nombreuses dispositions inconnues et les organise selon leur imporiance thématique. Au cours de ses premières decennies f'Alberia a adopte des dispositions qui on imposé l'anglais ef rdprimé les langues minoritaires. Plus récemment, toutefois, ces dispositions font preuve d'une plus grande tolérance pour la langue française et pour d'autres langues.

\section{TABLE OF CONTENTS}

I. INTRODUCTION ............................... 464

II. Historical ANAlysis of the Principal Language Provisions $\ldots . .468$

A. SECTION 110 OF THE NORTH-WEST TERRITORIES ACT,

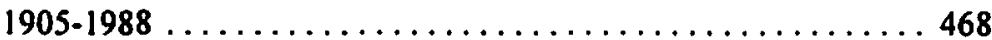

B. THE SCHOOL ACT, 1905 TO PRESENT ............... 473

C. SECTION 27 OF THE INTERPRETATION ACT, 1919-1980 ....... 479

D. THE LANGUAGES ACT, 1988 TO PRESENT ............. 482

III. Thematic OVerview of InCidental Language Provisions $\ldots \ldots \ldots 484$

A. The Official Languages of Alberta $\ldots \ldots \ldots \ldots \ldots \ldots 484$

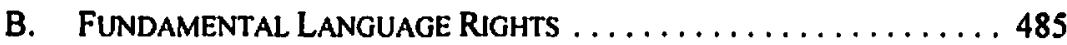

C. THE LANGUAGE of the Legisl.ATURE AND THE COURTS . . . . . . 485

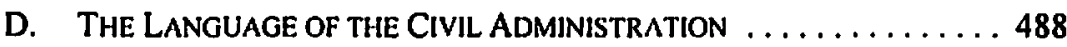

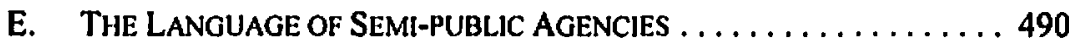

F. The Language of Labour Relations $\ldots \ldots \ldots \ldots \ldots \ldots \ldots 492$

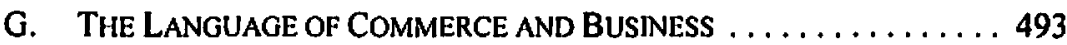

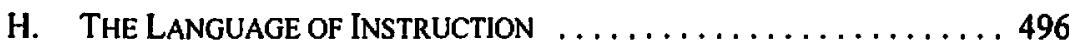

IV. CONCLUSION .............................. 497

Professor of Political Science, Faculté Saint-Jean, University of Albena. The author gratefully acknowledges the research assistance provided by Katharine McDonough who, in 1992, diligently sifted through several hundred statutes in search of legislative provisions relevant to language use. 


\section{INTRODUCTION}

Legislative provisions that relate to language use deal with a matter of fundamental importance. As the Supreme Court of Canada in 1988 declared in Ford v. Quebec (A.G. ), "[I]anguage is not merely a means or medium of expression; it colours the content and meaning of expression. It is a means by which a people may express its cultural identity. It is also the means by which one expresses one's personal identity and sense of individuality." In support, the Court cited the internationally-renowned sociolinguist, Joshua Fishman:

[L]anguage is not merely a means of interpersonal communication and influence. It is not merely a carrier of content, whether latent or manifest. Language itself is content, a reference for loyalties and animosities, an indicator of social statuses and personal relationships, a marker of situations and topics as well as of the societal goals and the large-scale value-laden arenas of interaction that typify every speech community. ${ }^{2}$

For this reason, the Supreme Court has treated language rights as fundamental human rights. In the Manitoba Language Rights Reference, it offered a now classic affirmation:

The importance of language rights is grounded in the essential role that language plays in human existence, development and dignity. It is through language that we are able to form concepts; to structure and order the world around us. Language bridges the gap between isolation and community, allowing humans to delineate the rights and duties they hold in respect of one another, and thus to live in society. ${ }^{3}$

Fundamental importance notwithstanding, relatively little is known about Alberta's legislative provisions for language use. Claude-Armand Sheppard, writing in 1965, described Canadian language law as a "relatively unexplored field" and his own pioneering study, The Law of Languages in Canada, as "no more than a preliminary survey of an extremely complex and important field of law." Alberta fared particularly poorly, rating only occasional paragraphs on a dozen pages scattered throughout his 414-page text. ${ }^{5}$ Sheppard cited six statutes, containing eight language provisions, ${ }^{6}$ all located in the Revised Statutes of Alberta 1955: the City Act, ${ }^{7}$ the Coal Mines Regulation Act, ${ }^{8}$ the Companies Act ${ }^{9}$ the Interpretation Act; ${ }^{10}$ the Municipal Districts Act; ${ }^{11}$ and the School Act. ${ }^{2}$ After examining each of these, he concluded that "the only language which enjoys official status in Alberta is English." 13

Ford v. Quebec (A.G.), [1988) 2 S.C.R. 712 at 748-49.

Joshua A. Fishman, The Sociology of Language: An Interdisciplinary Social Approach ro Language in Society (Rowley, Massachusetts: Newbury House Publishers, 1972) at 4.

Reference Re Manifoba Language Rights, [1985] I S.C.R. 721 at 744.

Claude-Armand Sheppard, The Low of Languages in Canada (Ottawa: Information Canada, 1971) at xviii.

Ibid. at 87-91, 170, 242, 251, 253-54, 260, 297-98.

Ibid. at 298.

R.S.A. 1955, c. 42, s. 96(1).

R.S.A. 1955, c. 47, ss. 72(c), 73(b).

R.S.A. 1955, c. 53, s. 130(3).

R.S.A. 1955, c. 160 , s. 40.

R.S.A. 1955 , c. 215, s. 85.

R.S.A. 1955, c. 297, ss. $385,386(1)$.

Sheppard, supra nole 4 at 298. 
Since that time, numerous works have appeared on Canada and selected provinces, ${ }^{14}$ but few have shed much further light on Alberta. In one, a province-by-province study of legislative provisions for minority-language education, Pierre Foucher evaluated each province in the light of constitutional guarantees recently entrenched in s. 23 of the Constitution $A c t, 1982 .{ }^{15} \mathrm{He}$ foresightedly judged the Alberta School Act unconstitutional because of its failure to provide for French-language minority schools. ${ }^{16}$ In another work, enticingly entitled "Official Bilingualism in Alberta," but limited largely to pre-1905 events, historian Kenneth Munro confirmed that "the study of the question of language in Alberta had largely been neglected." "In 1989, Edmund Aunger published an historical overview of provincial language law, but focused mainly on the legislature, courts and schools. ${ }^{18}$ This study raised more questions than it answered.

The failure to examine Alberta's language law more extensively may be due to a widespread suspicion that there is nothing much to be studied. Sheppard himself posited that a legislature's power to regulate language use might, in some instances, be exercised only occasionally. "It will tend to be unnecessary in linguistically homogeneous jurisdictions or in areas where, by custom or practice, a single language is used." "At first glance this would seem to apply directly to Alberta. According to the 2001 census the English language is overwhelmingly dominant: 82 percent claim English as their mother tongue, 96 percent speak English in their home and 99 percent are able to converse in English. Nevertheless, such homogeneity may be a new phenomenon. In 1916, for example, only 67 percent of Albertans spoke English as their mother tongue. ${ }^{20}$

Provincial ideology might also work against the adoption of such legislation. Alberta's political leaders have been frequent and vocal opponents of government intervention in various social and economic questions, including language matters, arguing that it would unjustly restrain personal liberty and individual choice. ${ }^{21}$ In 1992, for example. Alberta's

For Canada, see generally Réjean M. Patry, La législation linguistiqute fédérale (Quebec: Éditeur official du Quebec, 1981); M. Bastarache, ed., Les droits linguistiques au Canada (Montreal: Yvon Blais. 1986), published in English as Language Rights in Canada (Montreal: Yvon Blais. 1989): Joseph E. Magnet, Official languages of Canoda (Montreal: Yvon Blais. 1995): C. Michacl MacMillan. The Practice of language Rights in Canada (Toronto: University of Toronto Press, 1998). For various provinces, see also Jean-Claude Gimar, Les irois états de la politique linguistique du Québec (Quebec: Éditeur official du Québec. 1983): Gerard Snow. Les droits linguistiques des Acadiens du Nowveau Brunswick (Qucbec: Éditcur ofticiel du Québec, 1981); J.L. Gilles LeVasseur, Le stant juridique du français en Ontario (Ottawa: Presses de l'Université d'Otlawa. 1993): Jacqueline Blay, $L$ 'Arricle 23. Les péripéties législatives et juridiques du fait français au .Maniroba. 1870-1986 (Saint-Boniface. Manitoba: Éditions du Blc, 1987).

Pierre Foucher, Constitutional Language Rights of Official-Langzage Minorities in Canada (Otrawa: Canadian Law Information Council. 1985): Constitution Act. 1982. being Schedule B to the Canata Act 1982 (U.K.). 1982. c. 11.

1. Foucher, ibid. at $271-72$.

17 Kenneth Munro. "Oflicial Bilingualism in Alberta" (1987) 12:1 Prairic Forum 37 alt 37

1* Edmund $\Lambda$. Aunger, "Language and Law in the Province of Alberta" in P. Pupier \& J Wochtling. eds. Language and Lav: (Montrcal: Wilson \& Lafleur. 1989) 203.

: Canada. Census and Statistics Office, Census of Prairie Provinces: Population and dgriculure. 1916 (Ottawa: Printer to the King. 1918) at 250.

: C.B. Macpherson, in his classic study of Alberta's political system first published in 1953, was among the first to draw attention to the province's radical individualism. olten manilested in a profound opposition to government intervention and bureaucratic regulation. See C.B. Macpherson, Demecracy 
Premier, Don Getty, called for the repeal of federal language provisions, asserting that "bilingualism should be removed from the force of law. This would be a fundamental change in Canada. Bilingualism by choice not by law."22 Four days later a published poll revealed that 63 percent of the Alberta population supported Getty's proposal that "bilingualism should not be an official policy with the force of government behind it."23 As Doug Main, Alberta's Minister of Culture and Multiculturalism, explained, "Albertans, and many Canadians, don't like being told what to do."24

The incidental or ancillary nature of language in Canadian constitutional law provides an additional disincentive to study Alberta's language provisions. Language is not listed among the various legislative powers attributed by the Constitution Act, 1867 to the Canadian Parliament or to the provincial legislatures. ${ }^{25}$ It is incidental to these powers. As Peter Hogg explains, "for constitutional purposes language is ancillary to the purpose for which it is used, and a language law is for constitutional purposes a law in relation to the institutions or activities to which the law applies." ${ }^{26}$ In practical terms this means that language provisions have nearly always been buried in statutes dealing with other matters. Further, since these provisions are rarely indexed, researchers have, until recently, faced the daunting task of manually sifting through thousands of legislative acts. (Between 1906 and 1990, for example, the Alberta legislature adopted some 7,380 statutes.)

Fortunately, in 2001, the Alberta Heritage Digitization Project (AHDP) effectively removed this obstacle when it provided on-line access to retrospective Alberta statutes from 1906 to 1990, and to Alberta bills from 1950 to $1990 .^{27}$ This database reveals that, contrary to popular perception, the provincial government has legislated extensively on language questions. Between 1906 and 1980, for example, 112 statutes, or in other words, almost 2 percent of those adopted, made incidental provision for language use. ${ }^{28}$ Some contained generic provisions applicable to any language, including 33 that condemned the use of insulting, profane, blasphemous, offensive, abusive, indecent or obscene language - an interesting commentary on contemporary social concerns. However, 62 statutes, or I percent, regulated the use of a specified language, most commonly English but sometimes French. Typically, the legislators recognized the English language for use in provincial elections,

in Alberla: The Theory and Practice of a Quasi-party System (Toronto: University of Toronto Press, 1953). For more recent works on this theme, see Trevor Harrison \& Gordon Laxer, eds., The Trojan Horse: Alberia and the Future of Canada (Montreal: Black Rose Books, 1995) and Mark Lisac, The Klein Revolution (Edmonton: NeWest Press, 1995). For a specific commentary on the relevance of Alberta's neo-liberalism to language law, see Edmund $A$. Aunger, "De la répression da la tolérance: les contrariétés du néolibéralisme linguistique en Alberta" in J.P. Wallot, ed., La gouvernance linguistique: le Canada en perspective (Ottawa: Centre de recherche en civilisation canadiennefrançaise, fortheoming).

"Excerpts from Premier's Speech on the Constitution" The Edmonton Journal (10 January 1992) 17. "Getty's remarks harmful-poll" The Edmonton Journal ( 18 January 1992) A3.

"Doug Main fights for his Premier" The Edmonion Journal (26 January 1992) DI.

Constitution Act, 1867 (U.K.). 30 \& 31 Vict., c. 3, ss. 91, 92, reprinted in R.S.C. 1985. App. II, No. 5 Peter W. Hogg. Constizutional Law of Canada, 2d ed. (Toronto: Carswell, 1985) at 805.

"Retrospective Law Collection," online: Our Future, Our Past: The Alberta Heritage Digitization Project $<$ iwww.ourfutureourpast.ca/law/>.

We counted only those statutes that contained either the word "language" or a direct reference to a specitic language, such as "English" or "French." We did not count the numerous indirect references 10 language, implied in such words as "read." "write," "speak." "publish" or "interpret." 
professional services, municipal government, public records, judicial process, school instruction, industrial relations or consumer and corporate affairs. Their goal was often to ban minority languages, rather than to protect free speech or guarantee indjvidual choice.

In recent years the provincial legislature has intervened even more extensively. The Revised Statutes of Alberta 2000 include 34 statutes that provide for language use, or about 8 percent of the total. (When subordinate legislation is considered this number increases to 61 statutes, or 14 percent.) Again, many provisions are generic but in contrast to earlier times they are likely to protect individual rights in any language, rather than to impose prohibitions - only four statutes now regulate abusive or obscene language. There are also 19 statutes (or more than 4 percent) that contain provisions referring to a specific language. Although these still favour English, many also provide for the use of two or more languages. Current language provisions relate, for example, to the naming of business corporations, the appointment of interpreters at polling places, the proficiency of health professionals, the records of municipal councils, the languages of school instruction, the selection of jury panels, the examination of witnesses and the proving of wills. Further, there is now a statute, the Languages $A c t$, that provides exclusively for language use, specifically in the provincial legislature and courts. ${ }^{29}$

This article will examine Alberta's record in legislating language use and situate it in historical and thematic context. First it will study, in detail, the province's most important language provisions, which are found at various times in four different statutes: the NorthWest Territories Act, the School Act, the Interpretation Act and the Languages Act. The first two were not originally enacted by the provincial legislature but were carried over from the North-West Territories. The provincial constitution, the Alberta Act, provided in 1905 that "[a]Il laws and all orders and regulations" in vigour at that date in the Territories, would continue in the new province of Alberta until such time as the provincial legislature (or the federal Parliament, as appropriate) decided otherwise. ${ }^{30}$ The Canadian Minister of Justice, Charles Fitzpatrick, explained that "we are perpetuating the rights, whatever they may be, in the North-West Territories with respect to language, leaving it to the legislature to determine hereafter to what extent these rights may be maintained."

Second, this article will present a thematic overview of the province's language provisions, modeled on a modern provincial charter, Quebec's Charter of the French Language. ${ }^{32}$ In this overview, the major themes will be official languages, fundamental language rights, the language of the legislature and the courts, the language of the civil administration, the language of semi-public agencies, the language of labour relations, the language of commerce and business and the language of instruction. Although no direct comparisons are made, it is evident that Alberta's disparate and little-known language legislation, like Quebec's

Languages Act, R.S.A. 2000, c. L.-6.

Alberla Act, S.C. 1905, c. 3, s. 16, reprinted in R.S.C. 1970. App. II, No. 19. One of the new government's first priorities, then, was to consolidate the existing lawss. See Alberta. Department of the Attomey General, The Ordinances of the Norih-West Territories, Being an official consolidation of the Ordinances of the North-West Territories in force on August 3/st, 1905 (Edmonton: J.E. Richards, 1907).

House of Commons Debates (30 June 1905) at 8634

R.S.Q.. c. C-11. 
codified and well publicized language charter, has been strikingly comprehensive and farreaching.

\title{
II. Historical ANALySis Of THE Principal language Provisions
}

\section{A. SECTION 110 OF THE NORTH-WEST TERRITORIES ACT, 1905-1988}

In 1905 s. 110 of the North-West Territories Act, as amended in 1891 , continued to operate in the newly created province of Alberta. It thereby established English and French as the official languages of Alberta's legislature and courts:

\begin{abstract}
Either the English or the French language may be used by any person in the debates of the Legislative Assembly of the Territories and in the proceedings before the courts: and both those languages shall be used in the records and journals of such Assembly; and all ordinances inade under this Act shall be printed in both those languages: Provided, however, that after the next general clection of the lesgislative Assembly, such Assembly may, by ordinance or otherwise, regulate its proceedings, and the manner of recording and publishing the same; and the regulations so made shall be embodied in a proclamation which shall be forthwith made and published by the Lieutenant Governor in conformity with the law, and thereaner shall have full force and effect. ${ }^{33}$
\end{abstract}

The Canadian Parliament had originally adopted the first part of this provision in 1877 at a time when French-speakers made up some three-quarters of the North-West's nonindigenous population. ${ }^{34}$ Less than a decade later, however, the French had been reduced to a small minority by the flood of English-speaking immigrants from Ontario. Consequently, in 1889, the North-West Assembly — now entirely English - resolved to petition the federal government for abolition of the "dual language" provision. Parliament refused this petition but, in 1891, as a minor concession, added a new clause to s. 110 , permitting the Assembly to determine the language of its proceedings. This the Assembly did on 19 January 1892 by adopting a resolution moved by the head of the executive committee, Frederick Haultain: "That it is desirable that the proceedings of the Legislative Assembly shall be recorded and published hereafter in the English language only." 33 The Lieutenant Governor had already contracted for the French-language publication of the Legislature's 1890 proceedings and these duly appeared in $1892 .{ }^{36}$ However, these were the last Journals to be printed in French.

Not content with this small victory, Haultain and his government proceeded over the next two years to surreptitiously strip the French language of all official status. Disregarding the constitutional obligations, the executive terminated the French-language printings of

$" \quad$ North-West Territories Act, R.S.C. 1886, c. 50, s. 110 as am. by S.C. 189I. c. 22. s. 18.

$14 \quad$ Edmund A. Aunger, "The Mystery of the French Langunge Ordinances: An Investigation into Ofticial Bilingualism and the Canadian North-West-1870 to 1895" (1998) 13 C.J.L.S. 89 at 99 [Aunger. "French Language Ordinances"].

1s Legislative Assembly, Journals of the Second Legislative Assembly of the North-West Territories. Session 189/-92 (Regina, NWT: R.B. Gordon, 1892) at 110.

*. Aunger, "French Language Ordinances," supra note 34 at 120 
departmental reports and regulations in 1893 and of ordinances and gazettes in $1895 .^{37}$ As a result, in practice if not in law, English became the sole official language in the North-West Territories and then later in the provinces of Alberta and Saskatchewan. Subsequent legislators and jurists, often recent immigrants to Western Canada and blissfully ignorant of the region's legal history, blindly conformed to the new English-only regime. If they occasionally permitted the use of French, they perceived this to be a temporary privilege rather than a legal right.

For example, although the Alberta Legislative Assembly commonly published its statutes and regulations exclusively in English, Alberta's first French-speaking cabinet minister, Prosper Edmond Lessard, proudly announced in 1909 that the government had translated all its statutes into the French language. ${ }^{38}$ Two years later he backtracked somewhat claiming simply that the most useful laws were available in French, "telles que celles concernant les Battages, les clôtures, les animaux errants, les Sociétés d'Agriculture, les Privilèges d'ouvriers, les mauvaises herbes, la fabrication du beurre et du Fromage, les feux de prairie, les Mines de charbon, les mariages, et décès, etc. ${ }^{39}$ Nevertheless, Lessard's newspaper, Le Courrier de l'Ouest, warned its readers that, in spite of numerous requests, the government was still not convinced that there was a real demand. ${ }^{40}$ In subsequent years the newspaper decided to reprint some statutes in its own pages. ${ }^{41}$

Similarly, Alberta's courts functioned almost exclusively in the English language. In 1924, however, the Edmonton Bulletin reported a newsworthy exception where the litigants, their legal counsel and the judge, Lucien Dubuc, had all spoken French:

\footnotetext{
For perhaps the first time in the listory of the Province of Alberta. court proceedings were conducted entirely in the French language, with Judge Dubuc presiding, during the trial of a small debt casc. Usually when French or languages other than English is spoken, the evidence is translated by the interpreter into English, and all the arguments are in English. At the conclusion of this case, both lawyers congratulated the Court upon his presiding over proceedings so unique in Alberta. ${ }^{42}$
}

In fact, these French-language proceedings may not have been so unique. In 1921, for example, an English-speaking police constable, reporting on a criminal case previously heard in St. Paul, revealed, "I should here state that by consent of the Justice, all the evidence was taken in the French language and Mr. LaRue acting as clerk interpreted the evidence and wrote same in the English language, consequently I was unable to follow the case to any extent; Mr. A.U. Lebel acting on behalf of the complainant." ${ }^{943}$

Edmund A. Aunger, "Justifying the End of Official Bilingualism: Canada's North-West Assembly and the Dual Language Question, 1889-1892" (2001) 34 Can. J. Pol. Sc. 451 at 466.

"Le problème français de l'Ouest" Le Courrier de l'Ouest (Edmonton) (17 June 1909) 4.

P.E. Lessard, Editor of Le Courrier de I'Ouest, to A. Turgeon, Altomey General of Saskatchewan (29 September (911) Saskatchewan Archives Board, File M3-17K.

"Les ordonnances en français" le Courrier de IOuest [Edmonton/ (19 October 1911) I.

Sec for example "Acte des liqueurs" Le Courrier de l'Ouest (20 May 1915) 6

"French is used exclusively in court here for first time" Edmonion Bulletin (7 May 1924) 2.

Constable H. Allen, Alberta Provincial Police, Crime Report: Rex v. Routhier (1921). Criminal Case

Files of the Department of the Attomey General, Alberta Provincial Archives, File 72.26. It is now very difficult to verify the frequency of such occurrences, since the court records for most judicial districts in Alberta have been destroyed. In any case, these records were invariably written in English, with no 
The normal practice was, unquestionably, to refuse the use of French. In 1931, Taylor J. of Saskatchewan's Court of King's Bench affirmed that he himself had always directed "that all proceedings be had and taken in English." ${ }^{44}$ Further, "[s]ince the establishment of the Supreme Court of the North-West Territories no practice permitting the use of French in the Courts seems to have been countenanced." $\mathrm{HS} \mathrm{He}$ also claimed, by way of explanation, that the North-West Territories $A c t$, and s. 110 in particular, had been expressly "repealed by the Parliament of Canada in 1906."' Evidently, Taylor was not aware that Parliament had quickly corrected this error by adding the qualifying phrase "except as regards the provinces of Saskatchewan and Alberta."

In addition, Taylor contended that Saskatchewan's disestablishment of the North-West courts had superceded s. $110{ }^{48} \mathrm{He}$ also claimed that provincial statutes and regulations, such as the Judicature Ordinance and the Rules of Court, recognizing English as the language of practice and procedure, now stood "as expressing the legislative will of to-day." "49 A half century later, Greschuk J. of Alberta's Court of Queen's Bench adopted this same line of reasoning in the Lefebvre case. ${ }^{50} \mathrm{He}$ expressed the opinion that "once the province abolished or replaced the courts of the Territories and established or constituted their own provincial courts, s. 110 became inapplicable to the new provincial courts." Interpretation $\mathrm{Act}^{32}$ had declared English to be the language of public records including, necessarily, the written proceedings of a provincial court, Greschuk concluded that "if s. 110 continued in force in Alberta after the courts of the Northwest Territories ceased to exist, it was repealed by implication, operation of law or unavoidable interference."

In the 1985 Paquette case, however, Sinclair J. lucidly rebutted these arguments. ${ }^{34} \mathrm{He}$ noted, tactfully, that neither Taylor J. nor Greschuk J. were apparently aware that s. I 10 had been revived in 1907 with respect to Alberta and Saskatchewan. ${ }^{35}$ Since that time, it had never been repealed, either expressly or by implication. (Moreover, since the Paquette case concerned criminal procedure, such repeal was not within the competence of the provincial government.) "Accordingly, s. 110 gives an accused and his counsel the right to use the French language for all purposes during the preliminary hearing and trial." ${ }^{\text {66 }}$ Justice Sinclair

indication of the language actually spoken.

G.E. Taylor, "The Onticial Language of the Courts in Saskatchewan" (1931) 9 Can. Bar Rev. 277 at 277.

lbid. at 283.

Supra note 44 at 280 . He was apparently referring here to Schedulc A of the Revised Statufes of Canada. 1906. See Norih-West Territories Act, R.S.C. 1886, c. 50, as rep. by 1906, c. 43, s. 4 (Schedule A).

Act 10 amend Schedule A to the Revised Statutes 1906, S.C. 1907, c. 44, s. I(c).

Supra note 44 at $281-82$.

Ibid. at 282.

R. v. Lefebvre (1982), 69 C.C.C. (2d) 448 (Alta. Q.B.) Lefebvre] reprinted in Jules Deschenes, Ainsi parierent les tribunaux..., vol. 2, Confits linguistiques au Canada. 1968-1985 (Montreal: Wilson \& Lafleur) 661. All pinpoint references are to the Deschints reprint.

Deschenes, ibid. at 669.

R.S.A. 1922, c. 1, s. 35.

Supra note 50 at 674.

Paquette v. R. in Right of Canada (1985), 40 Alta. L.R. (2d) 38 (Q.B.) [Paquette (1985)].

Ibid, at 43-45.

lbid. at 39. 
further concluded that the judges involved "must be able to comprehend the French and the English languages in both their spoken and written forms." Appeal agreed that "[s]ection 110 of the North-West Territories Act does apply in Alberta," thereby upholding the right to use the French language in provincial courts. ${ }^{58}$ On the other hand, it also determined that this did not include the right to a judge who understood the language. Nevertheless, by this time Alberta's judiciary had already conducted 21 trials in the French language, including two jury trials. ${ }^{39}$

Language use in Alberta's Legislative Assembly experienced similar vicissitudes. English was widely deemed to be the sole official language and in 1971 Claude-Armand Sheppard concluded that "English has been the only language ever used in the legislature or in any of its committees." In fact, French had been spoken on various occasions, but its use was considered a privilege to be reluctantly granted or rudely denied. Documenting this use is difficult, however, since there was no published Hansard prior to 1971, and newspaper reports are often the only available source.

In 1936 La Survivance reported that J.William Beaudry, the Member of the Legislative Assembley (MLA) for St. Paul and a member of the governing Social Credit party, had delivered parts of his maiden speech in French. ${ }^{61}$ His remarks, including praise for the contribution of the province's French-speaking pioneers, were warmly received: "De chaleureux applaudissements ont vivement souligné ses paroles." On the other hand the Edmonton Journal noted in 1952 that Liberal leader J. Harper Prowse's intervention, opposing the planned elimination of "foreign" languages taught in grade 10, had met with a more frosty response. ${ }^{62} \mathrm{He}$ had spoken briefly "in what the house assumed was French" to illustrate that the French tongue was not widely understood or appreciated; but a government backbencher, rising on a point of order, questioned "whether members were allowed to speak French in the legislature." ${ }^{163}$ A decade later a new L,iberal opposition leader, Michael Maccagno, commenting in French on Canadian bilingualism, endured more blatant bigotry. A government member allegedly demanded: "Mr. Speaker, have the honourable member from Lac La Biche speak white."64 The Speaker permitted Maccagno to continue, but requested an oral translation. By contrast, in 1975, Socred backbencher Charles Drain playfully enlivened question period by asking Premier Peter Lougheed, in French, why he had spoken only one of Canada's two official languages at the opening of the Canada Winter Games in Lethbridge. ${ }^{65}$ The unilingual Lougheed deftly handed the question off to the Government House Leader, Louis Hyndman, who replied in French.

lbid. at 69 [emphasis in original].

R. v. Paquette (1987), 55 Alta. L.R. (2d) ] (C. A.) [Paquetfe (1987)].

Alberta, Government, Alberta's Language Policy (22 June 1988) at 7.

Supra note 4 at 297.

"Premier discours du député de St-Paul à la l.égislature" la Sirvivance [Fdmonton/ (26 February 1936) 3.

"Language Courses Questioned As Education Budget Studied" The Edmonton Journal (20 March 1952) I.

lbid.

M. Maccagno, "Excerpt from unpublished memoirs." See Alberta, Legislative Assembly, Standing Committee on Privileges and Elections, Standing Orders and Printing. Minutes (22 June 1987) exhibit 12.

Legislative Assembly, Alberta Hansard, 15 (12 February 1975) at 588 (Mr. Drain). 
In 1986, however, an MLA claimed that the use of French was a legal right and in support cited s. 110 of the North-West Territories Act. ${ }^{66}$ Leo Piquette, the newly-elected New Democrats (ND) member for Athabasca-Lac La Biche, proudly announced that ' $\mathrm{j}$ 'ai choisi ce moment historique pour indiquer fortement que comme un député dans l'Assemblée legislative de l'Alberta, j'assume mes droits selon l'article 110 des statuts de Northwest Territories Act de 1891." ${ }^{267}$ His comments were greeted with silence, but no evident opposition. Nevertheless, almost a year later, when he again spoke in French, this time during question period, his words sparked a bizarre political crisis. " "Thank you, Mr. Speaker. To the Minister of Education, le ministre de l'éducation. Mr. Speaker, these questions are pertaining to section 23 of the Constitution Act signed by this province on April 19, 1982. Les franco-Albertains attendent impatiemment depuis 1982."69 At this point the Speaker intervened, called Piquette to order and commanded: "En anglais, s'il vous plait.... The Chair directs that the questions will be in English or the member will forfeit the position." Piquette immediately contested the Speaker's decision, claiming that "the language rights guaranteed in Section 110 of the North West Territories Act were never extinguished and do still obtain in the Legislative Assembly of the Province of Alberta." 70

Government members were incredulous, refusing to believe that this statute, previously unknown to them, could still have any contemporary relevance. Nevertheless, they sent the question to the Standing Committee on Privileges and Elections for further study. There the parliamentary counsel, Michael Ritter, further compounded the confusion, erroneously proclaiming that the statute was indeed irrelevant and rudely disparaged expert testimony to the contrary. He asserted that the Alberta Legislative Assembly was completely sovereign and supreme in its powers, unfettered either by law or by courts, and thus "the assumption of parliamentary independence and the right to regulate one's own Chamber prevails." Moreover, he advised the members that convention could extinguish statute and that in Alberta the convention was "basically one of a unilingual Legislature."" The committee accepted these arguments and decided, on a motion from the Deputy Premier, David Russell, that Leo Piquette had breached the privileges of all members of the Assembly "by his failure to uphold the absolute authority of the Speaker to rule on points of order and to accept such rulings without debate or appeal." apologize to the Assembly." " Later the same year, the Legislature also amended its standing orders to assert that "the working language of the Assembly, its committees, and any official publications recording its proceedings shall be in English."'s

\section{Supra note 33.}

Legislative Assembly, Alberta Hansard, 7 (20 June 1986) at 160 (Mr. Piquette).

See Timothy Christian, "L'Affaire Piquette" in David Schneiderman, ed., Language and the State: The Law and Politics of Identity (Cowansville, Quebec: Yvon Blais, 1991) at 107.

Legislative Assembly, Alberta Hansard, 32 (7 April 1987) at 631.

L. Piquette, MLA Athabasca-Lac La Biche, to D. J. Carter, Speaker, Legislative Assembly of Alberta (8 April 1987). See Albera, Legislative Assembly, Standing Committee on Privileges and Elections, Standing Orders and Printing, Mimuses (6 May 1987) exhibit 2.

Alberta, Legislative Assembly, Standing Committec on Privileges and Elections, Standing Orders and Printing, Minutes (23 June 1987) at 154.

Ibid. at 174.

Alberta, Legislative Assembly, Standing Committee on Privileges and Hilections, Standing Orders and Printing, Minutes (25 June 1987) at 212.

lbid.

Legislative Assembly, Alberta Hansard, 99 (27 November 1987) at 2093 (Hon. Leslie G. Young). 
A few months later, in $R$. v. Mercure, ${ }^{76}$ the Supreme Court of Canada confirmed unequivocally that s. 110 of the North-West Territories $A \mathrm{Cl}^{\text {" }}$ was still in vigour. It noted that laws giving expression to language rights possess an almost constitutional nature and can only be repealed by "clear legislative pronouncement." The restructuring of the courts or other institutions has no effect on such provisions since "different courts can come and go but the law remains." ${ }^{78}$ Similarly, the Court ruled that the adoption of certain rules of court indicating that English is the language of proceedings should not be interpreted as interfering with vested rights. Where there is a conflict between a fundamental law and other specific legislation, "the human rights legislation must govern." ${ }^{\text {"79 }}$ Further, the long-standing practice of using English exclusively in the debates, statutes and court proceedings does not in any way change the statutory protection accorded the French language since "statutes do not, of course, cease to be law from mere disuse. ${ }^{380}$ In sum:

Section 110 of The North-IVest Territories Act was a law existing at the establishment of the province. Since no provision of the Saskarchewan Act was inconsistent with s. 110 or was intended as a substitute for it, and since there was no amendment of the provisions of that section with respect to the language of the statutes and of the proceedings in the courts, it follows that $\mathrm{s}$. 110 continues in effect for that purpose and that the statutes of Saskatchewan must be enacted, printed and publistred in English and French and that both languages may be used in the Saskatchewan courts. ${ }^{81}$

Saskatchewan moved quickly to deal with this awkward situation by adopting, in both official languages, a law explicitly declaring that s. 110 of the North-West Territories Act "does not apply to Saskatchewan with respect to matters within the legislative authority of Saskatchewan." ${ }^{82}$ Alberta, as we shall see, followed suit shortly afterwards. ${ }^{83}$

\section{B. TIE SCHOOL ACT, 1905 TO PRESENT}

Section 136 of the North-West Territories' School Ordinance had established English as the sole language of school instruction and in 1905 this provision too was carried over into the new province of Alberta. Specifically, as the section's first paragraph stated: "All schools shall be taught in the English language but it shall be permissible for the board of any district to cause a primary course to be taught in the French language. ${ }^{.84}$

Daniel Mowat, the MLA for South Regina, had successfully proposed this provision in 1892 , arguing that "we would never have true patriotic feeling in the country until there was one language." ${ }^{85}$ A year earlier he had introduced a similar proposition, but without any concession to the French language. Mowat justified his revised proposal by explaining that the "provision to make the teaching of English compulsory was rendered necessary on

[1988] I S.C.R. 234 at 237 [Mfercure].

Supra note 33.

Mercure, supra note 76 at 263.

Ibid. at 267.

Jbid. at 255 .

lbid. at 236.

Sec Language Act, S.S. 1988, c. I.-6I, s. I3

See Langwages $A c t$, S.A. 1988, c. L-7.5, s. 7.

School Ordinance, C.O.N.W.T. 1905, c. 75, s. 136.

"The Legislature" The /Regina/ Leader (18 August 1892) 1. 
account of the large influx of foreigners. An exception was made in favor of teaching a primary course in French, as the French were fellow Canadians." ${ }^{186}$ This "exception" allowed a course in reading and composition at the primary level (that is, during the first two years of schooling).$^{87}$ However, the prescribed text, a bilingual reader, was - perhaps by design - best suited for teaching English to the French-speaking population. When the course was offered, the allotted time generally varied between a half-hour and a full hour per day, strictly controlled by the local school inspector. ${ }^{88}$

A second paragraph, adopted in 1901 after German-speakers had petitioned the Legislative Assembly for school instruction in German, permitted a school board to "employ one or more competent persons to give instructions in any language other than English" subject to the departmental regulations and on condition that this not interfere with the required school program and that the costs be collected directly from the parents concerned." The Department of Education regulations subsequently provided some clarification: "Such instruction shall be given between the hours of three and four o'clock in the afternoon of such school days as may be selected by the board and shall be confined to the teaching of reading, composition and grammar. The text books used shall be those authorized by the Commissioner of Education." 90 The program was seldom implemented, however, since, as the legislators had probably anticipated, the immigrant population lacked the means to pay for it.91

Justifiably, John R. Boyle, Minister of Education from 1912 to 1918, could boast that in Alberta "we have no Bi-lingual schools.... English is the only language permitted to be used as the medium of instruction in our schools." ${ }^{92}$ In 1915, during a by-election held in Whitford, he accused the Conservative opposition of catering to the immigrant vote by advocating the establishment of Ukrainian schools. ${ }^{93}$ The opposition, eager to prove its innocence, immediately moved a resolution: "That this House place itself on record as being opposed to Bi-lingualism in any form in the School system of Alberta, and as in favour of the English language being the only language permitted to be used as the medium of instruction in the schools of Alberta, subject to the provisions of any law now in force in the Province in that effect." 94 The Liberal government, caught in its own trap, voted with the opposition and the resolution passed unanimously.

"Legislative Assembly" The Edmonton Bulletin (22 August 1892) 2.

"7 Yvette T.M. Mahé, "L'enseignement du français dans les districts scolaires bilingues albertains, 1885 . 1939" (1992) 4 Cahiers franco-canadiens de l'Ouest 291 at 294-95.

* Jbid. at 295.

* School Ordinance, O.N.W.T. 1901, c. 29, s. 136.

* Regulations of the Department of Education (Regina: John A. Reid, 1903), s. 25.

1 In 1916 Bishop Legal received legal advice that this regulation conflicted with the provision for a French-language primary coursc taught during school hours. His solicitors also noted that "no other language other than French has been taught between the hours of three and four in the afternoon limiled to grammar, reading. and composition, except perhaps in some isolated districts where the teacher had taken the liberty to do as she pleased." See S.T. Rusak, Relations in Education berween Bishop Legal and the Alberta Governmemt. 1905-1920 (M.Ed. Thesis, University of Alberta, 1966) al 94-95.

$" \quad$ Cited in J. Castell Hopkins, The Canadian Anmual Review of Public Affairs, $19 / 3$ (Toronto: Annual Review Publishing Company, 1914) at 655.

"La question bilingue à la législature d'Alberta" Le Courrier de I'Ouest (8 April 1915) 1.

it J. Castell Hopkins, The Canadian Anmual Review of Public Affairs. 1915 (Toronto: Annual Review Publishing Company, 1916) at 702. 
In the meantime, the French-speaking community lobbied cautiously for the right to expand French-language instruction in their schools. Knowing that the government would not amend the School Ordinance ${ }^{95}$ for this purpose, French leaders astutely focused instead on the interpretation given the existing statute. In particular, they sought to redefine the expression "a primary course" to mean any instruction given during the first two years of schooling. In 1925 these efforts finally paid off and the Department of Education discretely published new instructions for the teaching of French:

\begin{abstract}
In all schools in which the board by resolution decides to olfer a primary course in French, in accordance with Sec. 184 of the Scliool Ordinance, IPrenclı shall be for the French-speaking children one of the suthorized subjects of study and may be used as medium of instruction for other subjects during the first school year. Oral English must, however, from the beginning be included in the curriculum as a subject of study. During the second year and after the child has learned to read in the mother tongue, the formal teaching of reading in English shall be begun. From Grade III on, a period not exceding one hour each day may be allotted to the teaching of French. ${ }^{96}$
\end{abstract}

Four decades later the provincial government modified the School $A C t^{97}$ to formally confirm this practice. A 1964 amendment provided that French might be the language of instruction up to grade nine on condition that in grades one and two "at least one hour a day shall be devoted to instruction in English," in grade three "not more than two hours a day shall be devoted to instruction in French," and in grades four through nine "not more than one hour a day shall be devoted to instruction in French." ${ }^{.98}$

In 1968, the national tidal wave of official bilingualism, marked by a federal Official Languages $A c t,{ }^{99}$ carried the province along in its wake. The Government of Alberta again amended the $S$ chool $A \mathrm{Cl}^{100}$ this time to permit the use of French for up to "50 percent of the total period of time devoted to classroom instruction each day" in grades three through twelve. ${ }^{101}$ In 1971 it also took a significant step towards multiculturalism by placing all other languages, the so-called "heritage languages," on a footing similar to French: "A board may authorize (a) that French be used as a language of instruction, or (b) that any other language be used as a language of instruction in addition to the English language, in all or any of its schools." ${ }^{102}$ The Minister of Education later permitted instruction in these languages, notably Ukrainian, during 50 percent of each school day for grades one through three..$^{103}$ In 1976 this was extended to grades four through six, in 1980 to grades seven and eight, and, finally, in

Supra note 84.

Alberta, Legislative Assembly. "Instructions concerning the Teaching of French in the Lilementary Schools of the Province of Alberta" in Sessional Papers (1925), Vol. 20, Paper No. 4-e at I.

Supra note 12.

An Acl to amend the School Act. S.A. 1964, c. 82. s. 43, amending R.S. A. 1955, c. 297. s. 386 [Schoof Amendment Act, 1964).

Official Languages Act, S.C. 1968-69. c. 54.

Supra note 98.

An Act to amend the School Act. S.A. 1968, c. 89. s. 24. amending R.S.A. 1955. c 297. s 386 |Sichoot Amendment Act, 1968].

An Act to amend the School Act. S.A. 1971, c. 100. s. 18, amending R.S.A. 1970, c. 329. s 150|.School Amemdment Act. 1971].

P. Lamoureux, Bilingual Schooling in Alberta (Edmonton: Alberta Education. 1984) at 3-4. 
1983 to grades nine through twelve. ${ }^{104}$ In a 1988 report the government declared that: "Alberta Education supports the provision of opportunities for students who wish to acquire or maintain languages other than English or French so that they may have access to a partial immersion (bilingual) program or second language courses in languages other than English or French." ${ }^{105}$ The same report noted that some 2,775 students were enrolled in these bilingual programs, chiefly in Ukrainian (1,362), but also in Hebrew (458), German (339), Arabic (265), Mandarin (234) and Polish (117). ${ }^{106}$ They accounted for 1.5 percent of all enrollments in provincial language programs or courses.

In 1976 the provincial government again expanded the number of hours available for French-language instruction by reducing the English-language minimum. As before, schools were obliged to offer at least one hour of English instruction per day in grades one and two but they were now freed from the $\mathbf{5 0}$ percent rule for subsequent grades. Instead, Frenchlanguage schools could limit their English instruction to 190 hours per year in grades three through six, 150 hours in grades seven through nine and 125 hours in grades ten through twelve. ${ }^{107}$ This meant, in effect, that French-language instruction could occupy up to 80 percent of regular class time.

On 23 February 1978 Premier Peter Lougheed signed a national statement on minority language rights: "Each child of the French-speaking or English-speaking minority is entitled to an education in his or her language in the primary or secondary schools in each province wherever numbers warrant." ${ }^{108}$ The following day, however, he issued a distinctly Albertan clarification:

It should be recognized that the provision of French language instruction is not limited to those students whose moller tongue is French. In fact, because of Alberta's population mix and distribution, many boards must rely on large numbers of students whose mother tongue is other than French in establishing classes where French is used as the language of instruction. It will continue to be our policy to allow admission to French language programs regardless of mother-longue. ${ }^{109}$

Alberta thereby diverged from the national consensus, refusing to distinguish between immersion schools designed for the English-speaking majority and Francophone schools intended for the French-speaking minority.

This refusal took on added significance when, several years later, the Constitution Act, 1982 guaranteed the right of official language minorities to have their children instructed "in minority language educational facilities provided out of public funds." 10 Since Alberta's French-language educational facilities were, in reality, immersion schools and not minority schools, they fell considerably short of the constitutional requirement. In 1982 a group of

\footnotetext{
(ii) Ibid.

I'is Alberta, Government of Alberta, Language Education Policy for Alberia (Edmonton, 1988) at 16.

Iiv. Sbid. at 22.

III' French Language Regulations, Alla. Reg. 250/76.

IIIX Canada, Premiers' Conference, "Statement on Language" (23 February 1978).

III") Alberta, Government of Alberta, "Statement by Premier Peter Lougheed and Education Minister Julian Koziak RE: Minority Language Insiruction" (24 February 1978).

Constitution Act, 1982, supra note 15, s. 23(3).
} 
French-speaking parents, led by Jean-Claude Mahé, Angéline Martel and Paul Dubé, attempted to obtain French minority schooling for their children by contacting, first, the Minister of Education and then, on his advice, the Edmonton Public School Board and the Edmonton Catholic School Board. When their efforts failed, the parents took the province to court, claiming that the School Act ${ }^{\prime \prime \prime}$ contravened s. 23 of the Constitution Act, $1982 .^{1 / 2}$ In 1985 Purvis J. of the Alberta Court of Queen's Bench ruled in their favour and ordered the province to make specific provision for French minority schools. ${ }^{13}$ Two years later, Kerans J., speaking for the Alberta Court of Appeal, confirmed this decision. ${ }^{114}$

The province responded in 1988 by adopting a School Act that now recognized, albeit awkwardly and ambiguously, the right to French minority schooling: "If an individual has rights under section 23 of the Canadian Charter of Rights and Freedoms to have his children receive school instruction in French, his children are entitled to receive that instruction in accordance with those rights wherever in the Province those rights apply." parents appealed to the Supreme Court of Canada claiming that the provincial legislation still failed to provide for minority schools, that is, schools managed and controlled by the Frenchspeaking minority. The Court agreed and, in 1990, ruled that the province must enact legislation granting exclusive authority to the French minority for decisions

relating to the minority language instruction and facilities, including: (a) expenditures of funds provided for such instruction and facilities; (b) appointment and direction of those responsible for the administration of such instruction and facilities: (c) establishment of programs of instruction: (d) recruitment and assignment of teachers and other personnel; and (e) the making of agreements for education and services for minority language pupils. 110

The Government of Alberta reacted negatively to this decision and initially threatened to use the so-called "notwithstanding" clause in order to override these language rights. "7" When advised that s. 23 was not subject to derogation, it reluctantly began searching for a school management model that would meet the standards defined by the Supreme Court. It appointed a French Language Working Group charged with recommending an appropriate model and then later a Francophone School Govemance Implementation Committee, charged with implementing the model. Finally, in 1993, the Legislative Assembly amended the School $A \mathrm{Cl}^{118}$ to provide for minority school boards, described formally as "Regional authorities for Francophone Education Regions" 19 By this time, there were already 13 French minority schools in the province, with a total enrollment of 2,105 students. ${ }^{120}$

111 Supra note 12.

112 Sipra note 15.

113 Mahé v. Alberta (1985), 39 Alta. L.R. (2d) 21.5.

114 Mahé v. Alberta (1987), 54 Alta. I.R. (2d) 212.

IIS School Act, S.A. 1988, c. S.3.I, S. S(1).

ik. Mahe v. Alberfa, [1990] I S.C.R. 342 at 345.

117 For a more detailed examination of the Alberta government's response to the Mahe decision, see Edmund A. Aunger, "Dispersed Minorities and Segmental Autonomy: French-Language School Boards in Canada" (1996) 2 Nationalism and Ethnic Politics 191 at 205-11.

11. Supra note 115.

II) School Amendment Act, 1993, S.A. 1993, c. 24, s. 24

120 Aunger, supra note 117 at 207. 
The revised school system featured seven new school districts or "Francophone Education Regions" that together covered the entire province, although each centered on a different urban cluster: Edmonton, Calgary, St. Paul-Bonnyville, Peace River-Fahler, Fort McMurray, Red Dear and Lethbridge. The regional authorities were responsible for the management and control of French minority schools in their region, including: tracking eligible students and facilitating their education in French, representing French-speaking parents, promoting French-language instruction in the province, maintaining links with other regional authorities and developing rules and regulations for French education. ${ }^{121}$ Further, as school boards, they were empowered by the School $A C l$ to establish policies for the provision of educational services and programs, to employ teachers and non-teaching personnel including administrators and supervisors, to maintain and furnish their real property, to make rules respecting the attendance and transportation of students and generally, to deal with all matters within their jurisdiction. ${ }^{122}$

The Fédération des parents francophones de l'Alberta was charged with organizing the first elections, held in March 1994. The regional authorities, themselves, were responsible for subsequent elections, to be held every three years beginning in October 1995. (Legislative reforms resulted in the most recent elections being delayed until May 2002.) Any Canadian citizen 18 years or older and an Alberta resident is eligible for election to a regional authority. ${ }^{123}$ The right to vote, however, is limited to any "Francophone" who has "a child who is a student enrolled in a school operated by the Regional authority."124 The Government of Alberta is authorized to extend voting rights to the members of a prescribed "class of individuals," presumably the province's French-speaking population, but has never done so. The restricted franchise was designed to prevent opponents of French minority education from taking over regional authorities, and then eliminating the French-language schools. As such, it reveals much about Alberta's French-speaking community and its bitter struggle for minority language rights.

The revised School Act published in $\mathbf{2 0 0 0}$ contains a preamble that, for the first time, highlights minority schooling, proclaiming that

the Regional authority of a Francophone Education Region has a unique responsibility and the authority to ensure that both minority language educational rights and the rights and privileges with respect to separate schools guaranteed under the Constitution of Canada are protected in the Region, such that the principles of francophone educational governance are distinct from, not transferable to nor a precedent for, the English educational system. ${ }^{25}$

This responsibility was reiterated more precisely in a 2001 amendment requiring that "[a] Regional authority must designate each school either as a public school or as a separate

Alberta, Alberta Education, Gude de mise en oeuvre de la gestion scolaire francophone (Edmonton: School Business Adninistration Services, 1994) at 9.

Supra note 115, ss. 44, 74. 77. (According to s. 3 of the School Amendment Act, 1993, supra note 119. any reference in the law to a school board is deemed to include a regional authority.)

School Act, R.S.A. 2000, c. S-3, s. 256(3)

Ibid., s. 256(I).

Ibid., Preamble. 
school." 126 In 2003-2004 the province could boast five regional authorities administering 18 French Catholic schools and seven French Public schools with a combined total of 3,638 registered students. ${ }^{127}$

\section{SECTION 27 OF THE INTERPRETATION ACT, 1919-1980}

On 17 April 1919 the Alberta Legislature adopted an amendment to the Interpretation $A c t,{ }^{128}$ affirming English as the province's official language. It appended an additional interpretive rule to the $A c t$ 's already lengthy 60-point list: "Unless otherwise provided where any Act requires public records to be kept or any written process to be had or taken it shall be interpreted to mean that such records or such process shall be in the English language."129 The province had inherited some 124 ordinances from the North-West Territories, regulating a wide range of activities including elections, government departments, public printing, public health, civil justice, marriage, professions and trades, companies, municipalities, schools, agriculture, liquor sales, tax assessment and insurance - and the great majority did indeed require the keeping of public records or the taking of written process. ${ }^{130}$ The Elections Ordinance, for example, described in exquisite detail a plethora of required written records and procedures including the issuing of writs, the publication and posting of notices, the taking of oaths and statements, the printing of ballots, the recording of electoral information, the keeping of poll books and record books, the certification of nominations and elections, the serving of summons and the filing of appeals. ${ }^{131}$

Oddly, the English language amendment was buried deeply within an omnibus housekeeping bill modifying 51 different statutes, formally entitled An Act to amend The Factories Act, The Liquor Act, The Soldiers ' Home Tax Exemption Act, and certain other Acts and Ordinances. ${ }^{132}$ The Bill made only a fleeting appearance in the legislature, attracting little attention and no debate. Its second reading, late on a Monday afternoon, was completely upstaged by lengthy and heated exchanges concerning the practice of chiropractic. The legislative reporter's summary was revealingly brief and inarticulate: "The house agreed without discussion to the second readings of two acts introduced by the attorney general, one to amend the factories act, the liquor act, and other effected by the special revisions of certain measures; and the other to postpone the commencement of certain other acts."

John R. Boyle, now the Attorney General, had sponsored the Bill and, whatever his reasoning, his timing was impeccable. Alberta was at the time a fervid hotbed of pro-English exclusivism. The Great War had recently ended and the province was celebrating its returning heroes, virtually all British-born or British-origin volunteers. Gerald Friesen has observed that there was, at the time, a "growing hatred of all things German," combined with des conseils scolaires francophones de l'Alberta, 2003). S.A. 1906, c. 3. 
prejudice against "southeastern Europeans, including especially the Ukrainian immigrants from the Hapsburg empire," and also "European pacifists, including Doukhobors and Mennonites."134 A few months earlier the federal govemment had suppressed publications in "enemy" languages including German, Russian, Ukrainian, Hungarian and Finnish. ${ }^{135}$ Only a week prior to the Bill's second reading, Attorney General Boyle had reminded the provincial house that "[he] won [his] election by the English vote," unlike an opponent who had advocated "Russian schools for Russian people." 36 "I stood for one school and one language, and naturally my majority came from the English electors."137

The legislature's inconspicuous support for the English language amendment contrasted dramatically with the outspoken stance of the Orange Order. A few weeks earlier, on 20 March 1919, at meetings addressed by the Mayor of Edmonton and the Lieutenant-Governor of Alberta, the Grand Orange Lodge of Alberta adopted the following resolution:

That in the interests of a united Canada urgent representation be made to the federal and provincial governments, so far as their respective jurisdictions are concerned. (1) to enact legislation whereby the English language shall be the sole medium of instruction in every grade of every school under government control, and (2) to enforce the existing law of the land so that within the province of Alberta the English language only shall be read officially on any public form or document, or in any public office. school or assembly. ${ }^{138}$

The Orangemen also called upon the federal govermment to "enact legislation preventing the immigration of persons from alien enemy countries or of such extraction, for a period of twenty years and further, to deport all such aliens now in Canada unless they furnish ample proof of loyalty." 139

In 1922, when Alberta's statutes were consolidated, the English language provision was numbered s. 35, labelled "English as official language" and published in revised form: "Whenever by any Act public records are required to be kept or any written process to be had or taken, the records or process shall be kept, had or taken in the English language."140 The 1942 consolidation retained this same wording and labelling, although the provision now became s. $40 .^{141}$ The 1955 revised statutes made minor changes to the text, but retained the number and label. ${ }^{142}$ Three years later, however, the legislature adopted a new Interpretation $A C t$, still keeping the English language provision, but this time as s. 27, with the label "Public records" and the text: "Where by an enactment public records are required to be kept or any written process to be had or taken, the records or process shall be had or taken in the English language."143 The provision was repealed in $1980 .{ }^{144}$ (The frequent renumbering may have

Gerald Friesen, The Canadian Prairies: A History (Toronto: University of Toronto Press, 1984 ) at 352. lbid. at 354.

"Spirited Passage between the Attomey General and Jas. Weir enlivens Work on Estimates" The [Edmonton] Morning Bulletin (8 April 1919) 1.

lbid.

"Resolutions passed by the Orange Lodge" The (Edmonton] Morning Bullesin (21 April 1919) I.

lbid.

Interpretation ACI, R.S.A. 1922, c. I, s. 35.

Imerpretation Act, R.S.A. 1942, c. I, s. 40.

Interpretation Act, R.S.A. 1955, c. 160, s. 40.

Interpretation Act, S.A. 1958, c. 32, s. 27.

Interpretation Act, S.A. 1980, c. 70 , s. 41. 
caused occasional confusion: Claude-Armand Sheppard reported, mistakenly, that it had been repealed in $1958 .^{145}$ )

Alberta's English language provision was rarely applied by the courts. In a 1965 ruling on the validity of a French-language bill of sale, Tavender J. described the provision as "the only reference in any Alberta statute to the use of the English language," but he found it of no assistance in the case at hand. ${ }^{146}$ In his view the bill was a private document, while the Interprefation Act referred to public records, defined as "certain records or documents which are kept by certain government officials whose duty it is to inquire into and record permanently matters and facts about public matters." ${ }^{47}$ Justice Tavender instead looked to earlier legislation, including the North-West Territories $A \mathrm{Cl}^{148}$ determining thereby that French was the "customary language of the people," and that its use "continued to be lawful." 149 Further, in an unexpected aside, he concluded, "In the light of the above statutes it would appear that in the Province of Alberta French is a permissive language in the Legislative Assembly and in the Courts."150

This startling conclusion was largely ignored. In Lefebvre, for example, Greschuk J., took no notice, holding that "if s. 110 continued in force in Alberta after the courts of the Northwest Territories ceased to exist, it was repealed by implication, operation of law or unavoidable inference."|sI More specifically, Greschuk J. held that "s. 27 of the Interpretation Act, 1958, undermines the necessary intendment of s. 110 and the latter accordingly must be held to be repealed by implication." 152 At the provincial court level, Marshall J. found similarly that the English language provision had repealed Alberta's official bilingualism, the Lefebvre decision being a binding authority. ${ }^{153}$ However, on appeal Sinclair J. disagreed, ruling that s. 110 had never been repealed. ${ }^{154}$ Justices Stevenson and Irving of the Court of Appeal upheld this decision on further appeal. ${ }^{155}$ Nevertheless, neither they nor Sinclair J. made any reference to the Interpretation Act.

In 1980, when the Alberta legislature adopted a new Interpretation Act, the English language provision finally disappeared - as quietly as it had originally appeared. ${ }^{156} \mathrm{~A}$ government backbencher introduced the Bill, but gave no explanation or justification. ${ }^{157}$ Nor

iss Sheppard, supra note 4 at 91

la. General Motors Acceptance Corporation of Canada Ldd. v. Perosmi (1965), 5 I D.L.R. (2d) 724 at 736 (Alta. Dist. Ct.).

Jbid.

Supra note 33.

Ibid. at $730 \mathrm{rr}$.

lbid. at 734.

Lefebwe (1982), supra notc 50 at 674.

lbid. at 673.

Bencen Her Majesty The Queen and Luc Paqueffe (26 October 1984). (Alta. Prov. (1) [unreported] reprinted in Jules Deschìnes. Alnsi parlèrem les tribumaux... . vol. 2, Couflits linguistiques au Camuda. 1968-1985 (Montreal: Wilson \& Lafleur) 683 at 689, 693.

Paquette (1985), stupra note 54.

Paquette (1987), supra note 58.

Supra note 144, c. 70.

Legislative Assembly, Alberta Hansard, 64 (20 November 1980) at 1613 (Mr. Wolstenholme) 
was he ever called upon to do so. The Bill sailed through the assembly, including committee of the whole, without question or comment. ${ }^{138}$

\section{THE LANGUAGES ACT, 1988 TO PRESENT}

On 25 February 1988, less than a year after the Alberta Legislative Assembly had denied ND member Leo Piquette the right to speak French and bullyingly denigrated his protests, the Supreme Court of Canada ruled that s. 110 of the North-West Territories Act, ${ }_{159}$ providing for official bilingualism, did indeed remain in effect in Saskatchewan and, by implication, in Alberta. ${ }^{160}$ This meant that both English and French could be spoken in the provincial legislature and courts. Further, the Legislature was obligated to publish its statutes in both languages.

Nevertheless, the province could, if it wished, adopt a statute to repeal this provision although, paradoxically, any such statute had to "be enacted, printed and published in the English and French languages." 161 Thus, on 22 June 1988, Attorney General James Horsman introduced a bilingual bill entitled the Languages $A c t$, providing that "[s]ection 110 of The North-West Territories Act, chapter 50 of the Revised Statutes of Canada, as it existed on September 1, 1905, does not apply to Alberta with respect to matters within the legislative authority of Alberta." ${ }^{162}$ Horsman justified the new Bill without embarrassment and without apology:

Mr. Speaker, we are dealing with the reality of the fact that the Mercure decision has said that an Act passed in 1886 - which had never been used in this province, never been implemented, had fallen into complete disuse in the Northwest Territories prior to Alberta becoming a province in 1905 - is still the law because of a technicality.... We have now been told by the Supreme Court of Canada how we must proceed in order to change that antiquated, unused piece of legislation which was a hangover from $1886 .^{163}$

The Assembly's first step had been to suspend the standing order, adopted only a few months earlier, on November 27, establishing English as the language of the Legislature, its committees and its publications, and preventing members from speaking French without the Speaker's prior consent. The Attorney General then submitted his new Bill, arguing, exclusively in English, that it was "fair and reasonable and practical and recognizes the reality of Alberta and the distinct nature of Alberta society." 10 the Liberal leader, Nick Taylor, retorted that it was "nothing more than summoning up the prejudices of centuries past and taking a poke at a defenseless minority under the guise that it reflects Alberta's reality." 165 Attorney General Horsman was the only member of the governing Conservative party to participate in the debate. Nine members of the 20-person opposition intervened, however, and several made comments in French. The Speaker conducted the proceedings in both languages, announcing each reading and each vote in English and in French, as did the

\footnotetext{
15* Legislative Assembly, Alberta Hansard, 68 (26 November 1980) at 175I (Mr. Wolstenlolme).

15.) Siupra note 33

(1) Mercure, supra note 76

14.1 Ibid. al 280.

11: Supra note 83, s. 7 .

It. Legislative Assembly, Alberta Hansard, 102 (30 June 1988) at 2171 (Mr. Horsman).

ind bid. at 2170.

leis lbid.
} 
chairman in committee of the whole. In one typically ironic turn of events, however, the chairman refused to accept an opposition amendment calling for the translation of selected laws into French because the amendment itself had not been translated into French. ${ }^{166}$

The Languages Act suppressed s. 110 of the North-West Territories Act and its requirement that all statutes be enacted and printed in French. This measure drew public attention and was hotly debated. However, the $A c t$ also provided that " $[\mathrm{m}]$ embers of the Assembly may use English and French in the Assembly"167 and that "[a]ny person may use English or French in oral communication" in court proceedings. ${ }^{168}$ These provisions attracted relatively little public discussion.

There has been a modest increase in French language activity in the Legislature since 1988, but its use remains relatively symbolic. For example, in 1999 Nancy MacBeth, the leader of the official opposition, spoke in French when she congratulated the government on its creation of a Secrétariat aux affaires francophones but then she repeated her remarks in English. ${ }^{169}$ Two years later the president of this secretariat, MLA Denis Ducharme, also spoke in French when he announced that the Association canadienne-française de l'Alberta was celebrating its 75 th anniversary. ${ }^{170}$ Ducharme did not repeat this announcement in English, but he did provide a written translation, and this too was printed in Hansard."11

French continues to get short shrift in civil matters before Alberta's courts, largely because the province has failed to guarantee the presence of a bilingual judge. As Mclntosh J. of the Provincial Court has pointedly explained:

\footnotetext{
With respect, you can do all the talking in French that you like but in Alberta, with respect. Provincial matters are conducted in English, so if you're going to communicate with me you 'll have to do it in English, or you will have to have somebody here that can assist you in English. But this trial is conducted in English. That's the law in Alberta, for Provincial Statutes. ${ }^{17}$
}

In criminal matters, of course, the government must comply with federal law and this grants an accused, on application, the right to "be tried before a justice of the peace, provincial court judge, judge or judge and jury, as the case may be, who speak the official language of Canada that is the language of the accused or, if the circumstances warrant, who speak both official languages of Canada."173

Legislative Assembly, Alberla Hansard, 17 (16 March 1999) at $\$ 43$ (Nancy MacBeth). Legislative Assembly, Albersa llansard, vol. Il (30 May 2001) at 933 (Mr. Ducharme). Ibid.

R. v. Desgagné (13 June 1996), Peace River A 06115443 T at 3 (Alta. Prov. Ct.); cited in Canada, Department of Justice and Department of Canadian Heritage, Annotated Language Laws of Canada, 2d ed. (Ottawa: Department of Public Works and Government Services, 2000) at 208. 


\section{Thematic Overview of Incidental Language Provisions}

The historical summary of the principal language provisions in Alberta dispels a common myth. Contrary to popular perception, the provincial government has, over the past century, intervened significantly to legislate language use, thereby restricting personal liberty and individual choice. However, this summary, focusing on only four statutes, does not adequately capture the full breadth of this intervention, nor the immense number of provisions.

For this reason, it is appropriate to present a thematic overview of Alberta's language provisions, modeled on a modern provincial charter, Quebec's Charter of the French Language. ${ }^{174}$ The Québec Charter, of course, produced shock waves that reverberated across the country. Its impact on Quebec's economic, political, social and cultural sectors was sufficient, according to Guy Rocher, to provoke a second Quiet Revolution, more powerful than the first. ${ }^{173}$ The Québec Charter's impressive scope is evident in Title l: Status of the French language, including nine chapters: The official language of Québec; Fundamental language rights; The language of the legislature and the courts; The language of the civil administration; The language of the semi-public agencies; The language of labour relations; The language of commerce and business; The language of instruction; and Miscellaneous.

The thematic overview of Alberta's language legislation uses this same organizational structure in order to demonstrate that Alberta's provisions, like Quebec's, have been strikingly comprehensive and far-reaching. The chief differences have not been in content or breadth, but in timing. The Québec Charter was adopted dramatically, in one fell swoop, in 1977 and in spite of subsequent modifications, still remains in force today. The Alberta legislation was adopted secretively, one piece at a time, over more than a century and its most oppressive provisions are no longer in effect. Such provisions are no longer necessary, having accomplished their desired effect - the creation of a largely unilingual province.

\section{A. The Official LaNGuages of Alberta}

Section 110 of the North-West Territories Act established English and French as the official languages of the province's legislature and courts. ${ }^{176}$ In obvious contradiction, a 1919 amendment to the Interpretation Act formally recognized English alone as the official language for public records. ${ }^{17}$ In 1988 the Languages Act finally resolved this anomaly when it repealed s. 110 , and then validated all acts and regulations enacted, printed and published exclusively in English. ${ }^{178}$ Nevertheless, it also granted French a very limited official status by permitting its use for oral communication in the courts and the legislature. ${ }^{179}$

R.S.Q.. c. C-II [Québec Charler].

Guy Rocher, "La politique et la loi linguistiques du Québec en 1977" in Michel Plourde, ed., Le français au Queibec: $\$ 00$ ans d'histoire ef de vie (Quebbec: Conseil de la langue française, 2000) 273 at 283.

Supra note 33.

Statute Low Amendment Act, S.A. 1919, c. 4, s. 30, amending S.A. 1906, c. 3, s. 7.

Supra note 83.

Ibid., ss. 4-5. 


\section{B. FUNDAMENTAL LANGUAGE RIGIITS}

\section{LEGISLATURE AND COURTS}

The North-West Territories Act provided that "[e]ither the English or the French language may be used by any person in the debates of the Council or Legislative Assembly of the territories and in the proceedings before the courts." ${ }^{80}$ The Languages $A c t$ now provides that "[m]embers of the Assembly may use English and French in the Assembly"181 and that "[a]ny person may use English or French in oral communication in proceedings before the ... courts." 182

\section{SCHOOL INSTRUCTION}

Since 1988, Alberta's School Act has provided that "[e]very student is entitled to receive school instruction in English." ${ }^{83}$ In accordance with the Canadian Charter of Rights and Freedoms, ${ }^{184}$ the same $A C l$ also declares, since 1993, that a "student who is enrolled in a school operated by a Regional authority is entitled to receive school instruction in French." 18 s

\section{MENTAL HEALTH}

In 1972 the Mental Health Act recognized the right of a person, upon becoming a formal patient or the subject of renewal certificates, to "be informed of the reason for his admission or the issuance of renewal certificates in simple language" and to be given a written statement describing the authority for the detention and explaining the right of appeal. ${ }^{186}$ Further, "[i]n the event of language difficulty, the board shall obtain a suitable interpreter and provide the explanation and written statement ... in the language spoken by the formal patient or his nearest relative." ${ }^{187}$ Since 1988 a patient may claim this right only after two admission certificates or two renewal certificates have been issued. ${ }^{188}$

\section{The Language of the Legislature and the Courts \\ 1. ASSEMBLY DEBATES}

The North-West Territories Act recognized the right to speak either English or French in the legislative assembly. ${ }^{189}$ In 1987 the Alberta Legislative Assembly adopted a standing order providing that "the working language of the Assembly, its committees and any official

Supra nole 33, s. 110.

Languages Act, supra note 83, s. $5(1)$.

Jbid., s. 4(1).

Supra nole 123, s. 9.

Part I of the Constitution Act, 1982, being Schedule B to the Canada Act 1982 (U.K.), 1982. c. I1.

Supra note 123, s. 10(3).

S.A. 1972, c. 118 , s. $36(1)$.

Jbid., s. 36(3).

Mental Healh Act, R.S.A. 2000, c. M-13, s. 14(1).

Supra note 33. 
publications recording its proceedings shall be in English." 190 Since 1988 the Languages $\mathrm{ACt}$ has reaffirmed the right to use either English or French in the legislature. ${ }^{191}$

\section{STATUTES AND RECORDS}

The North-West Territories Act required that statutes be printed in both English and French, and that "both those languages shall be used in the records and journals of such Assembly." 192 The Languages $A c t$ now states simply that "[a]Il acts and regulations may be enacted, printed and published in English"193 and, similarly, that the "Standing Orders and records and journals of the Assembly may be made, printed and published in English."

\section{ASSEMBLY ELECTIONS}

The 1909 Alberta Election Act required that the returning officer in each riding publish a proclamation "in the English language" listing the place and time for nominations, the boundaries of the polling subdivisions and the places and times for voting. ${ }^{195}$ In 1980 the phrase "in the English language" was suppressed. ${ }^{196}$

The same $A c t$ also made provision for an interpreter: "If the person desiring to vote is unable to understand the English language the deputy returning officer shall enter a remark to that effect opposite his name in the poll book and may allow him to retire from the polling place until a competent interpreter can be procured." 197 A second paragraph added, somewhat disconcertingly: "If no such interpreter is found or presents himself at the polling place the voter shall not be allowed to vote." 198 A much revised version of the first provision still remains in effect: "A deputy returning officer may appoint in the prescribed form an interpreter at a polling place to translate questions and answers concerning voting procedures for persons not conversant in the English language."199 However, the second paragraph, permitting the disenfranchisement of non-English-speaking electors, was repealed in $1980 .{ }^{200}$

\section{JUDICIAL PROCEEDINGS}

The North-West Territories Act provided that either English or French might be used "in the proceedings before the courts." 201

The 1914 Alberta Rules of Court required that non-English-speaking witnesses be provided with an interpreter during written interrogatories:

Supra note 75.

Supra note 83, s. 5(1).

Supra note 33.

Supra note 29, s. 3.

Ibid., s. 5(3).

S.A. 1909 , c. 3, s. 121.

Alberia Election Act, 1980 , S.A. 1980, c. 61, s. $51(1)$.

Supra note 195, s. 175.

Ibid., s. 175(2).

Alberia Election Act, R.S.A. 2000, c. E-I, s. 78

Supra note 196, ss. 72, 196.

Supra note 33, s. 110. 


\begin{abstract}
Where a witness does nol understand the English language the ordet or commission shall, unless otherwise ordered, be executed with the aid of an interpreter nominated by the examiner or commissioner and sworn by him 10 interpret truly the questions to be put to the witness and his answers thereto, and the examination shall be taken in English. ${ }^{202}$
\end{abstract}

The current Rules of Court include this same provision expressed in almost identical words. ${ }^{203} \mathrm{~A}$ similar procedure is followed during the taking of affidavits when it appears that "the deponent does not understand the English language." $20 \mathrm{~s}$

The Rules of Court also require that when a request is received from a foreign court the "letter of request for service shall be accompanied by a translation thereof in the English language, and by two copies of the process or citation to be served, and two copies thereof in the English language." ${ }^{205}$ Similar rules apply to the enforcement of foreign judgments. ${ }^{206}$ The Reciprocal Enforcement of Judgments Act reiterates the procedure:

\footnotetext{
Where a judgment sought to be registered under this Act is in a language other than the Linglish language, the judgment or the exemplification or certified copy of it, as the case nay be, shall have attached to it fot all purposes of this Act a translation in the English language approved by the Court, and on the approval being given the judgment is deemed to be in the English language. ${ }^{207}$
}

Alberta's Languages $A c t$ permits any person to "use English or French in oral communication in proceedings" before the province's courts. ${ }^{208}$

\title{
5. JURIES
}

Since 1982 the Jury $A c t$ has listed persons who might be exempted from jury duty, including "a person who is unable to understand, speak or read the language in which the trial is to be conducted." ${ }^{209}$ On these same grounds a party to civil proceedings is entitled to any number of challenges for cause. ${ }^{210}$ The Jury Act Regulation, adopted in 1983, provides further information on the selection of jurors and notes that "the selection of a jury panel for a jury of French-speaking persons may be made from a list, compiled by the sheriff, of French-speaking persons who have been previously summoned for a jury panel."211

R.S.A. 2000, c. R.6, s. 4. This provision first appeared in the Reciprocal Enforcement of Judgments Act. 1958, S.A. 1958, c. 33, s. 5. For a similar provision, see the Reciprocal Enforcement of Maintenance Orders Act, R.S.A. 2000, c. R-7, s. 14.

sus Supra note 29, s. 4(1).

:iv R.S.A. 2000, c. J-3, s. 5(I)(f). This provision first appeared in the Jury Act, S.A. 1982, c. J-2.1, s. $S(1)(f)$.

310 Ibid., S. 12(2)(f).

III Alta. Reg. 68/83, s. 2(2.1). 


\section{POLICING}

The Alberta Provincial Police, established in 1916 and then disbanded in 1930, required that all constables be "able to read and write the English language legibly."212

\section{The Language of the Civil Administration}

\section{OfFICIAL DOCUMENTS}

The official language clause found in the Interpretation Act, from 1919 until 1980 , established English as the language of the provincial administration: "Where by an enactment public records are required to be kept or any written process to be had or taken, the records or process shall be had or taken in the English language."213

\section{REQUESTS FOR SERVICE}

The Freedom of Information and Protection of Privacy Regulation permits an applicant to make an oral request for access to a record if "the applicant's ability to read or write English is limited."214 Presumably, the oral request should also be in English.

\section{RESIDENCY CRITERIA}

For purposes of vocational training grants, an individual is considered to be a resident of Alberta if he "lives or intends to live in Alberta" and "has been admitted to Canada for permanent residence and is pursuing a program of English as a second language."215

\section{ELIGIBILITY FOR LOCAL OFFICE}

The Town Act, adopted in 1912, required that candidates for election as mayor or councillor be "able to read and write the English language."216 The 1913 Edmonton Charter provided similarly that "[n]o person shall be eligible for election as mayor or alderman, unless he is ... able to read and write the English language."217 The Town and Village Acl and the Municipal District Act, as amended on 6 April 1945, also established English-language competence as a condition for eligibility to elected office. ${ }^{218}$ The 1951 City Act added an oral requirement: "No person shall be qualified to be elected mayor or a member of the council of a city unless, - (a) he can speak, read and write the English language."219 The 1968 Municipal Election Act repeated the same provision in somewhat modified form: "To be

21: Alberia Provincial Police Act, S.A. 1917, c. 4, s. 8.

i1. R.S.A. 1970, c. 189, s. 27.

i14 Alta. Reg. 200/95, s. 4(a).

21s Grants, Donations and Loans Regulation, Alta. Reg. 315/83, Schedule I, s. 1(2)(c)(iii).

211. S.A. 1911-1912, c. 2, ss. 15, 72.

217 S.A. 1913, c. 23, s. 21 .

218 Town and Village Act, R.S.A. 1942, c. 150, s. 44, as am. by S.A. 1945, c. 41, s. 4(a); Municipal District Act, R.S.A. 1942, c. 151, s. 133, as am. by S.A. 1945, c. 42, s. 20(a). 
eligible to become a member of the council a person must be (a) able to speak, read and write English." ${ }^{220}$ The language requirement was repealed in $1980 .{ }^{221}$

A 1951 amendment to the Irrigation Districts Act required that district trustees be "able to read and write in the English language."222 This provision apparently continued in force until 1999.223

The 1919 Municipal Hospitals Act limited eligibility for election to a hospital board to those "who can read and write the English language."224 Although this condition was repealed in $1947,{ }^{225}$ it resurfaced the following year in the Lloydminster Hospital Act. ${ }^{226}$

The 1970 School Election $A c t$ declared that to be "eligible to become a trustee a person must be (a) able to speak, read and write English or French., ${ }^{227}$ This was repealed in $1983 .{ }^{228}$

\section{LOCAL Elections}

The $1951 \mathrm{City} \mathrm{Act}$ provided that non-English-speaking voters might be assisted by an interpreter: "Where a voter does not understand the English language the deputy returning officer may allow an interpreter to translate the oath as well as any lawful question necessarily put to the voter, and his answers." 229 The 1957 Lloydminister Charter ${ }^{230}$ and the 1970 School Election Act ${ }^{231}$ included the same provision. The Local Authorities Election Act continues to permit the use of an interpreter: "If an elector does not understand the English language, the deputy [returning officer] may allow an interpreter to translate the statement as well as any question necessary for the proper purposes of the election put to the elector, and the elector's answers." ${ }^{332}$

Currently, in order to vote for a Francophone regional authority, an individual must be "a Francophone" who has "a child who is enrolled in a school operated by the Regional authority."233 The Local Authorities Election Forms Regulation provides sixteen different French language forms for use in these elections. ${ }^{234}$

S.A. 1968 , c. 66 , s. 10.

Municipal Election Amendment Act, S.A. 1980, c. 35, s. 5.

R.S.A. 1942, s. 22, as am. by S.A. 1951, c. 45, s. 4(b).

See Irrigation Disiricts Act, S.A. 1999, c. I-II, s. 35.

S.A. 1919, c. 8, s. 7(2).

Municipal Hospitals Amendment Act. S.A. 1947, c. 57, s. 7(a), amending S.A. 1929, c. 33, s. 31(1).

S.A. 1948 , c. 19, s. 35(4)(b).

S.A. 1970 , c. 101 , s. IG(a).

Local Authority Election Acl, S.A. 1983, c. I.-27.5, s. 172.

Supra note 219, s. 168.

Alla. Reg. 296/57, s. 146(1).

Supra note 227, s. 96(1).

R.S.A. 2000, c. L-21, s. 72(1). See also Municipal Election Act, supra note 220, s. 107(1).

School Act, supra note 123, s. 256 (1)(a).

Alta. Reg. 234/2000, Schedule 2. 


\section{MUNICIPAL ProceEDINGS}

The Rural Municipality Act, adopted in 1912, required the municipal secretary to "keep a full and correct record in the English language of the proceedings of every meeting of the council."235 On the other hand, the Town and Village Act, as amended in 1936, required the secretary-treasurer to "keep a full and correct record in the English or French language of the proceedings ... provided that, when required the secretary-treasurer shall furnish a certified copy of the records in the English language. ${ }^{.236}$ In 1968 a new Municipal Government Act reverted to the earlier English language provision, ordering that the municipal secretary "attend all regular and special meetings of the council and shall in the English language truly record in the minute book, without note or comment, all resolutions, decisions and other proceedings of the council."237 In 1994, this responsibility was redefined: "The chief administrative officer must ensure that (a) all minutes of council meetings are recorded in the English language, without note or comment."238

\section{E. The Language of Semi-public Agencies}

\section{COMMUNITY ORGANIZATIONS}

For tax exemption purposes a linguistic organization is defined as "an organization formed for the purpose of promoting the use of English or French in Alberta." ${ }^{.239}$ By comparison, a much broader definition is given to an ethno-cultural association; that is, "an organization formed for the purpose of serving the interests of a community defined in terms of the racial, cultural, ethnic, national or linguistic origins or interests of its members."240

\section{AlbER'TA CULTURAL HERI'TAGE FOUNDATION}

In 1978, the Cultural Development Amendment Act created the Alberta Cultural Heritage Foundation in order "to preserve the cultural wealth of our past including the language, art, music and rites of ethno-cultural groups in Alberta."241

\section{Registration in a Profession}

The Dental Association Act, as amended in 1912, set out the requirements for a license to practice dentistry in Alberta, including an examination offered twice yearly. ${ }^{242}$ This examination evidently required competence in the English language since, the following year, the Legislature voted to certify Edmonton resident Paul Karrer, "a fully qualified dental surgeon of Russia, Switzerland and the United States of America" who "does not write the 
English language and therefore cannot comply with the requirements of section 23 of The Dental Association Act."243

An applicant for registration as a professional member of the engineering, geological or geophysical professions must demonstrate "to the Board of Examiners that the applicant has a proficiency in the English language that is sufficient to enable the applicant to responsibly practice the profession of engineering, geology or geophysics."244

An applicant for registration as a registered nurse, ${ }^{245}$ a certified graduate nurse, ${ }^{246}$ a licensed practical nurse, ${ }^{247}$ a psychiatric nurse $e^{248}$ or an acupuncturist ${ }^{249}$ must, similarly, demonstrate a competence in the English language that is sufficient to practice the profession.

A candidate for registration as a medical laboratory technologist "must be sufficiently proficient in the English language to be able to provide professional services in English."250

An applicant for registration as a pharmacy intern must provide proof "that English is the applicant's first language, that the applicant has graduated from a training program in pharmacy that was offered in an English-speaking institution or that the applicant is sufficiently fluent in spoken and written English to carry on practice as a pharmacy intern."

An applicant for registration as a physical therapist, whose first language is not English, must submit "evidence satisfactory to the Registration Committee that the applicant has a comprehension of the English language sufficient to enable him to practice as a physical therapist." ${ }^{.252}$

A candidate for registration as registered veterinarian must provide "evidence satisfactory to the [Registration] Committee of his ability to communicate in English."2s3

Applicants for registration as a professional forester or a professional forest technologist, and regulated members applying for permits, may be required to provide information regarding the "language(s) in which the applicant provides professional services." ${ }^{354}$

\section{PATIENT RECORDS}

Acupuncturists must maintain complete patient records "in the English language."'s"

Act 10 Authorize Paul Karrer to Practice Denistry. S.A. 1913. c. 48. Preamble Engineering. Geological and Geophysical Professions General Regulation. Alta Reg. 150/99. s. 13(d) Nursing Profession Registration Regulation, Alta. Reg 453/83, s. 2(2)(b)

Certified Graduate Nurse Regulation. Alta. Reg. 455/83, s. 2(2)(b).

Licensed Practical Nurses Regulation. Alta. Reg. 103/97, s. $2(1)(\mathrm{c})$

Psychiatric Nurses Regulution. Alta. Reg. 509/87. s. 5(d).

Acupuncture Regulation. Alta. Reg. 42/88, s. 2(1)(t).

Medical Laboratory Technologists Profession Regulation, Alta. Reg. 255/2001, s. IO(1)

Pharmaceutical Profession Regulation, Alta. Reg. 322/94, s. 9(4)(b)(vi).

Physical Therapy Profession Gieneral Regulation, Alla Reg 298/85, s. 5(2)(c)

Veterinary Profession General Regulation, Alta. Reg. 44/86. s. 2(I)

Registered Professional Foresters Regulation. Alta. Reg. 75/2002. S 21(1)(vii): Regisferced Professional Forest Technologists Regulation, Alta. Rig. 76/2002, s 18(1)(vii).

Acupuncture Regulation. Alta. Reg. 42/88, s. 12(1). 


\section{SOLEMNIZATION OF MARRIAGE}

Since 1965, the Marriage $A C l$ has provided that "[n]o person shall solemnize a marriage when one or both of the parties do not understand the language in which the marriage ceremony is to be performed unless an interpreter is present to interpret and explain clearly to the party or parties the meaning of the ceremony."256

\section{F. The language of Labour Relations}

\section{BaSIC Foundation SKILLS}

A basic foundation skills program includes, by definition, a programme of instruction in "English as a second language." 257

\section{Certification in a Trade.}

The 1912 Boilers $A c t$ permitted a candidate taking the engineering certification exam, but who was "unable to speak the English language," to employ an interpreter, provided that the interpreter himself was not an engineer. ${ }^{258}$ Subsequent regulations, however, insisted upon a written examination, except for the fourth class certificate, and specifically prohibited the use of an amanuensis. ${ }^{259}$ Currently, candidates must successfully complete grade 11 English or equivalent. ${ }^{260}$

The 1913 Mines Act required that each applicant for a miner's certificate "satisfy the board that he is able to read and write in the English language."201 In 1930 this requirement was relaxed and a candidate needed only a "sufficient knowledge of the English language to enable him to give and understand working directions and warnings in English." ${ }^{.262}$ The 1955 Coal Mines Act demanded this same (reduced) level of English proficiency for both the miner's certificate and the miner's permit. ${ }^{263}$

In 1910, the Alberta Land Surveyors Act required that a person admitted as an articled pupil to a land surveyor must have previously passed an examination in English grammar. ${ }^{264}$ A 1949 amendment eliminated the detailed list of prerequisites and, instead, authorized the board of examiners to prescribe the required subjects. ${ }^{205}$ 
An applicant seeking admission to an examination for certification as a tool and die maker "shall provide translations into the English language, acceptable to the Director, of credentials in a language other than English." 266

\section{WORKPLACE REQUIREMENTS}

A 1924 amendment to the Boilers $A C t$ provided that "[e]very person engaged in the operation of a steam boiler shall speak the same language as the engineer in charge." ${ }^{" 267}$ This provision last appeared in 1957, in a slightly revised form: "Every person engaged in the operation of a steam plant subject to these regulations shall speak the same language as the engineer in charge of the shift."268

The Coal Mines Regulations Ordinance, carried over into Alberta from the North-West Territories, ordered that "[n]o person unable to speak and read English shall be appointed to or shall occupy any position of trust or responsibility."269 When the province adopted its own Coal Mines Regulation Act in 1930, this provision was no longer included. ${ }^{270}$

\section{EMPLOYMENT RECORDS}

In 1936 the Male Minimum Wage Act required that "[e]very employer shall keep in his principal place of business in the Province a true and correct record in the English language of the wages paid to and the hours worked each day by each of his employees, together with a register in the English language of the names, nationalities, ages and residential addresses of all his employees."271 This same requirement also appeared in the 1936 Hours of Work Act $^{272}$ and the 1947 Alberta Labour Act. ${ }^{273}$

\section{G. THE LANGUAGE OF COMMERCE AND BUSINESS}

\section{COMMERCIAL SIGNS}

A 1917 statute requiring the City of Calgary to adopt an early closing policy also ordered that exempted shops "expose in two prominent places in the front door, and in the front window a card not less than two feet square on which there shall be printed in English, in type of not less than one inch high, the following words only: "This shop is closed by law, except for the sale of (here state the goods, or any of them, mentioned in this

Tool and Die Maker Trade Regulation, Alta. Reg. 346/84, s. 4(4).

R.S.A. 1922, c. 191, s. 52, as am. by S.A. 1924, c. 3, s. 38(f).

Regulations with Respect 10 Engineers and Firemen, Alta. Reg. 93/57, s. R(a).

Coal Mines Regulations Ordinance, C.O.N.W.T. 1905, c. 16, r. 34.

Supra note 262.

S.A. 1936, c. 76, s. 14(1).

S.A. 1936, c. 5, s. 13(1)

S.A. 1947 , c. 8 , s. $10(1)$ 
subsection)." ${ }^{274}$ In 1923 the same provision was applied to the City of Edmonton ${ }^{275}$ and in 1951 to all Alberta cities, although the English-language sign was now to be "not less than twenty-two inches by twenty-eight inches." 276 The provision was repealed in $1968 .{ }^{277}$

\section{COMPANY REgISTRATION}

The 1929 Companies Act advised foreign companies that "[w]here any document required to be filed under this section is not in the English language, the Registrar may require a translation thereof, notarially certified." ${ }^{278}$ A 1968 amendment extended this provision to "extra-provincial" companies. ${ }^{279}$ It currently reads: "If all or any part of the charter is not in the English language, the Registrar may require the submission to the Registrar of a translation of the charter or that part of the charter, verified in a manner satisfactory to the Registrar, before the Registrar registers the extra-provincial corporation."280 The Cooperatives $A c t$ includes an equivalent provision. ${ }^{281}$

\section{CORPORATE NAMES}

According to the Interpretation $A c t$, a corporation that has "a name consisting of an English and French form or a combined English and French form" is vested with the power "to use either the English or French form of its name or both forms."282 The Business Corporations Act similarly recognizes that the name of a corporation "may be in an English form or a French form or in a combined English and French form and the corporation may use and may be legally designated by any of those forms." ${ }^{283}$ The Cooperatives $A c t,{ }^{284}$ the Insurance $A C t,{ }^{285}$ and the Loan and Trust Corporations $A c t,{ }^{286}$ all include similar provisions.

An Alberta registered corporation, cooperative or society may include in its name any letter of the English language alphabet, any Arabic numeral and any of twenty-three listed marks and symbols. ${ }^{287}$ On the other hand, a credit union or a loan and trust corporation is permitted the "letters of the alphabet used in the English or French language" as well as

Act to amend the Acts and Ordinances constinuing the Charter of the City of Calgary, and to validate Certain By-laws of the said city, S.A. 1917, c. 45, s. 19(4) [emphasis in original].

273 Act to amend the Acts constituting The Edmonton Charter and to validate By-law No. 2, 1923, of the City of Edmonton, S.A. 1923, c. 63, s. 6. Ste also An Act ro Amend the Acts Constituting The Edmonton Charter and to Validate Certain By-laws Auhorizing the Borrowing of Money, S. A, 1939, c. 102, s. 4.

2\%. City Acl, supra note 219, s. 381.

2" Municipal Government Act, supra note 237, s. 433.

27" S.A. 1929, c. 14, s. 135(3)(c).

27) An Act so amend the Companies Act, S.A. 1968, c. 13, 2(2), amending R.S.A. 1955, c. 53, s. 148(5).

Business Corporations Act, R.S.A. 2000, c. B.9, s. 280(3).

S.A. 2001, c. 28.1, s. 369(3).

R.S.A. 2000, c. 1-8, s. 16(e).

Supra note 280 , s. 10(6).

Supra note 281 , s. $16(2)$.

R.S.A. 2000 , c. $[-3$, s. 2$](2)$.

R.S.A. 2000 , c. L-20, ss. $20(2), 34(3)$.

Business Corporations Regulation, Alta. Reg. I18/2000, s. II(I); Cooperatives Regulation, Alta. Reg. $55 / 2002$, s. $10(1)$; Societies Regulation, Alta. Reg. $122 / 2000$, s. $10(1)$. 
"punctuation marks, symbols or other marks in common usage in the English or French language." 288

Corporations must include, as the last part of their name, one of a select number of English or French words, or abbreviations: "Limited," "Limité," "Incorporated," "Incorporé," "Corporation, "Ltd.," "Lté," "Inc," or "Corp."289 Similarly, cooperatives must include an appropriate English or French word (such as "cooperative," "co-operative" or "coopérative") in their names, ${ }^{290}$ as must trust companies ("trust" or "fiducje"). ${ }^{291}$ Only an incorporated insurance company may use the words "insurance company" or "insurance corporation" or "the French equivalents of those words" in its name. ${ }^{292}$

The Business Corporations $A c t$ declares that "a corporation may, outside Canada, use and may be legally designated by a name in any language form." 293

\section{COMPANY REPORTS}

The 1929 Companies $A c t$ required that all public companies file an annual report, including an audited balance sheet, "and if any such balance sheet is in a foreign language, there shall also be annexed to it a translation thereof in English, certified in the prescribed manner to be a correct translation."294 The phrase "not in English" now replaces "in a foreign language."295

\section{WILLS}

In 1976 Alberta enacted the rules regarding the so-called "international will," providing that a will "may be written in any language, by hand or by any other means." ${ }^{296}$ Nevertheless, when proving the signing of a will, Alberta's Surrogate Rules require that "[i]f a will is written in a language other than English, the applicant must give an affidavit in Form NC 10 verifying the will's translation into English." ${ }^{297}$ Further, if the deceased "did not fully understand English" at the time the will was made, the applicant must satisfy the court that the deceased appeared to fully understand the will."298

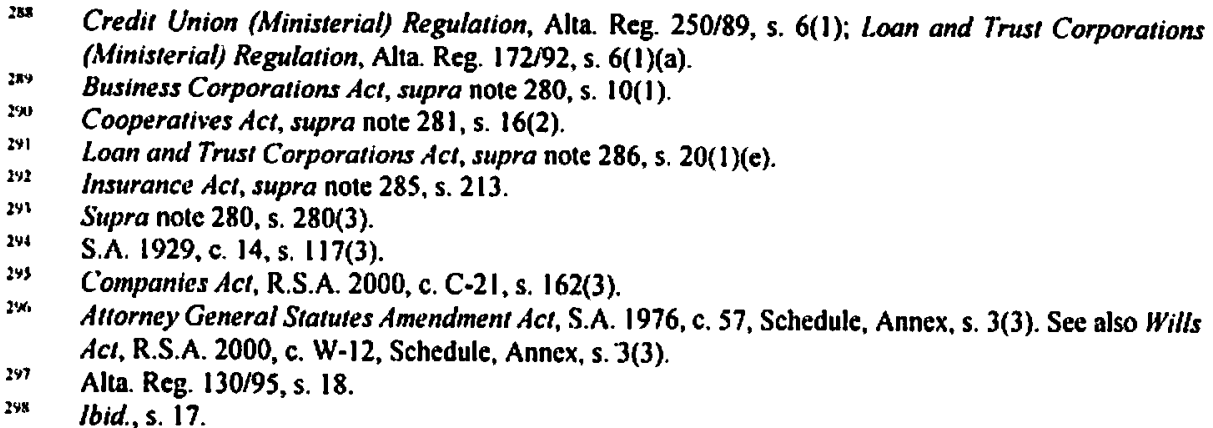




\section{H. THE LaNGUAGe OF INSTRUCTION}

\section{INSTRUCTION IN ENGLISH}

The North-West Territories' School Ordinance recognized English as the sole language of instruction: "All schools shall be taught in the English language but it shall be permissible for the board of any district to cause a primary course to be taught in the French language."2399 The 1988 School Act repealed this obligation, and replaced it with an entitlement: "Every student is entitled to receive school instruction in English." 300

\section{INSTRUCTION IN FRENCH}

The North-West Territories' School Ordinance permitted the teaching of a primary course in the French language. ${ }^{301}$ A 1964 amendment, however, provided for French language instruction "in grades one to nine inclusive but in that case (a) in grades one and two, at least one hour a day shall be devoted to instruction in English, (b) in grade three, not more than two hours a day shall be devoted to instruction in French, and (c) in grades above grade three, not more than one hour a day shall be devoted to instruction in French." ${ }^{\text {"302 }}$ Four years later a further amendment permitted French language instruction, in grades three through twelve, for up to " 50 percent of the total period of time devoted to classroom instruction each day." ${ }^{303}$ In 1976 the Minister of Education effectively increased the French language allowance to 80 percent of class time by reducing the English minimums. ${ }^{304}$

In 1989 the Minister of Education formally recognized French immersion as a program distinct from Francophone education, although both had the same hourly minimums for English language instruction. ${ }^{305} \mathrm{~A}$ decade later he repealed both the French Language Immersion Regulation ${ }^{306}$ and the French Language Regulation. ${ }^{307}$

\section{INSTRUCTION IN OTHER LANGUAGES}

The North-West Territories' School Ordinance permitted instruction in a language other than English (or French), but this could only be done after normal school hours and at the parents' expense. ${ }^{308}$ However, in 1971 an amendment provided that a "board may authorize (a) that French be used as a language of instruction, or (b) that any other language be used as a language of instruction, in addition to the English language, in all or any of its schools." ${ }^{309}$ In 1979 the Minister of Education ruled that in such cases the board was required to "ensure that English is used as the language of instruction for not less than $50 \%$ per day

m1

Supra note 84, s. 136.

S.A. 1988, c. S-3.1, s. 4. See also School Act, R.S.A. 2000, c. S-3, s. 9.

Supra note 84.

School Amemdment Act, 1964, supra note 98, s. 43, amending R.S.A. 1955, c. 297 , s. 386.

School Amendment Act. 1968, supra note 101, s. 24, amending R.S.A. 1955, c. 297, s. 386.

French Language Regularions, supra note 107, s. 2.

French Language Immersion Regulation, Alta. Reg. 36/89.

Education Repeal Regulation, Alta. Reg. 157/98.

Repeal Regulation, Alta. Reg. $222 / 99$.

Supra note 84, s. 136(2), (3).

School Amendment Act, 1971 , supra note 102, s. 18, amending R.S.A. 1970, c. 329, s. 150. 
for each pupil." 310 This Regulation was repealed in 1998. ${ }^{311}$ The School Act now declares, quite simply, that a "board may authorize the use of French or any other language as a language of instruction." 312

\section{Conclusion}

Fundamental importance notwithstanding, Alberta's language provisions have been widely ignored. Indeed, many still believe that Alberta has seldom legislated language use. This misperception is rooted in a neo-liberal ideology. (Would a supposedly non-interventionist government regulate its citizens' speech?) It is nourished by a discriminatory social impact. (Does the English-speaking majority care about measures that affect only a small linguistic minority?) It is maintained by ad hoc scattergun law-making. (Who will pick out the incidental provisions buried in a huge cauldron of legislation?)

This article has uncovered an extensive body of language law buried in a century of statutory and regulatory provisions. (And it may have only scratched the surface with respect to orders-in-council and regulations.) During the first several decades, Alberta legislated to ensure the use of English in a wide variety of domains, including government, justice, education, business and commerce. This legislative effort is impressive but troubling, given the longstanding and seemingly unthreatened status of the English language. Pierre Coulombe makes the point:

\footnotetext{
The rationale for limiting language rights outside Québec is assimilation to the English majority on grounds of cost-efficiency and/or cultural imperialism, for which there could be no valid justification. What I want to emphasize is that the situation is different outside Quebec: different of course because communal rights for French Canadians are a question of survival, making their violation all the more morally reprehensible, but different also because their violation is a case of plain repression against French-Canadian minorilies rather than the result of the excrcise of some communal English-Canadian right. ${ }^{313}$
}

In recent years, Alberta has exhibited a greater tolerance for the French language and for other minority languages, particularly in education. Prohibition has turned to acceptance. Judicial activism has created a growing system of French language schools, governed by French language school boards. Economic globalization has contributed to an increasing presence of French language corporate names, atop French language multinationals. Social development has encouraged a greater tolerance for French language communication in public institutions, including the legislature and the courts. Unfortunately, after decades of repressive language provisions, proportionately few non-English-speakers have survived to benefit from these changes. 